\title{
ADDRESSING NUTRIENT IMBALANCES IN ANIMAL AGRICULTURE SYSTEMS
}

\author{
Mahmoud Sharara ${ }^{1, *}$, Richard K. Kolesch ${ }^{2}$, Erin L. Cortus ${ }^{3}$, \\ Rebecca A. Larson ${ }^{4}$, John J. Classen ${ }^{1}$, Kevin A. Janni ${ }^{3}$ \\ ${ }^{1}$ Department of Biological and Agricultural Engineering, North Carolina State University, Raleigh, North Carolina, USA. \\ 2 Department of Biological Systems Engineering, University of Nebraska, Lincoln, Nebraska, USA. \\ ${ }^{3}$ Department of Bioproducts and Biosystems Engineering, University of Minnesota, St. Paul, Minnesota, USA. \\ ${ }^{4}$ Department of Biological Systems Engineering, University of Wisconsin, Madison, Wisconsin, USA. \\ * Correspondence: msharar@ncsu.edu
}

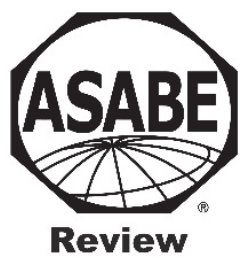

\section{Highlights}

- Animal agriculture intensification has greatly affected nutrient cycling and circularity in food production systems.

- Various nutrient balance methods are developed to improve nutrient management at various spatial scales.

- Balance-derived thresholds for action are identified using real-life examples in dairy production.

- Outreach and knowledge exchange are critical for development, adoption, and improvement of nutrient balance methods.

\begin{abstract}
Animal agriculture is a major consumer and generator of both macro- and micronutrients. Intensification and regional concentration of animal production, due to economic and logistical advantages, have altered nutrient fluxes in agriculture systems, causing increased stock of nutrients in soils and, consequently, their emission to air and transport to surface water and groundwater. Established nutrient and manure planning frameworks, while effective in addressing nutrient point sources and using manure to enhance fertility and soil quality, have not been wholly successful in addressing farmand region-scale challenges with nutrient concentrations. This review article addresses nutrient management issues associated with modern animal agriculture by advancing the use of nutrient budgets and balances. This is accomplished by establishing core concepts for nutrient budgets and balances as they apply to animal agriculture. Relevant spatial scales for these budgets are reviewed, including field, whole-farm, and watershed scales, along with proposed methodologies and data sources for each. This study also identifies existing region-and commodity-specific metrics (when available) for use as thresholds for corrective action toward more balanced nutrient budgets. Finally, recommendations for the community of practitioners, researchers, and educators are provided to address nutrient imbalance in animal agriculture systems. At farm and region scale, nutrient balance investments will be needed to strengthen accounting methodologies, develop appropriate data sources for measurements, identify thresholds for action, and apply the methods in appropriate settings and decisions. Data availability and uncertainty are recognized as key limitations facing wider adoption of these concepts, particularly considering data ownership and privacy concerns. The lack of transparent datasets that capture current animal production practices and their impact on manure composition and nutrient cycling is a gap facing these methodologies. The lack of engagement by practitioners and producers in the development phase of such tools greatly affects their adoption and utility. The need for continued engagement in establishing accepted methodologies, training, data collection, and education are crucial to establish farm-and region-scale methods and measure their value to nutrient planning over time.
\end{abstract}

Keywords. Farm scale, Livestock, Manure nutrients, Nutrient budget, Poultry, Regional scale.

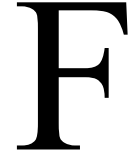
or centuries, agricultural systems have relied on circular production concepts in which nutrients cycle between crops and animal systems to facilitate sustainable food production (Galloway et al., 2013). However, in recent decades, transformations of cropping and animal production systems have altered nutrient flows,

\footnotetext{
(c) (1) $(\$$ The authors have paid for open access for this article. This ${ }_{\mathrm{BY}} \mathrm{NC}_{\mathrm{ND}}$ work is licensed under a Creative Commons AttributionNonCommercial-NoDerivatives 4.0 International License https://creative commons.org/licenses/by-nc-nd/4.0/

Submitted for review on 3 May 2021 as manuscript number NRES 14661; approved for publication as a Review Article by the Natural Resources \& Environmental Systems Community of ASABE on 11 January 2022.
}

posing challenges to sustainability. These changes include intensifying animal production in concentrated animal feeding operations (CAFOs) (MacDonald and McBride, 2009; Hilimire, 2011) leading to increasing reliance on resources external to the farm; decoupling of animal production from field cropping (Naylor, 2005; Garrett et al., 2020); growing demand for products as food, feed, biofuel, and bio-chemical feedstocks; and increasing reliance on nutrient-rich by-products from food processing and ethanol production for animal feed. These changes alter nutrient cycling in agroecosystems and increase consumption of mined resources, such as phosphate rock (Cooper et al., 2011) and fossil fuels, to satisfy nutrient demand. These agricultural system changes can exacerbate nutrient imbalances as nonpoint sources (NPS) of 
nutrient loss to water sources (i.e., Chesapeake Bay watershed, Mississippi River basin) (Boesch et al., 2001; Goolsby et al., 2000). These losses pose a significant threat to ecosystems and challenge the sustainability of both crop and animal production systems.

Quantifying nutrient fluxes and balances in animal and feed production systems is a valuable approach to assess animal agriculture's nutrient cycling and inform interventions to improve sustainability. As critical inputs to crop and animal production, nutrients such as nitrogen $(\mathrm{N})$, phosphorus $(\mathrm{P})$, and potassium $(\mathrm{K})$ are constantly cycling through agroecosystems as inputs (fertilizers, soil amendments, and atmospheric deposition) and outputs (harvested products, residues, and emissions). The mismatch between added and harvested nutrients from a land base creates an imbalance that changes the soil nutrient stock and results in nutrient losses to the environment and potential loss of crop or animal productivity (fig. 1). As such, nutrient balance accounting provides a quantitative tool to ensure an adequate nutrient supply to food systems while detecting surpluses (imbalances) that require management adjustments. Balances can be assessed for any system with well-defined boundaries in which nutrient imports and exports can be measured or estimated, such as a field or a farm. Whether directly or indirectly, nutrient balances already play an important role in documenting regulatory compliance in different contexts and may be critical to future supply chain initiatives to measure sustainability.

The authors, in cooperation with colleagues through a USDA Multistate Research Project (S1074: Future Challenges in Animal Production Systems: Seeking Solutions through Focused Facilitation) developed this article to summarize documented approaches for measuring nutrient balances at three scales: individual field, whole farm, and regional (watershed or political entity). Following a comparison of approaches for each scale, there is discussion regarding thresholds for action when imbalances resulting from nutrient imports in excess of exports lead to nutrient buildup (accumulation) within the system. These balance approaches promote varying strategies related to nutrient movement and use for animal agriculture. Finally, this article recommends research, policy, and farm management considerations connected with applying alternative nutrient balance methods for improving animal agriculture's ability to manage nutrients sustainably.

\section{NUTRIENT BALANCES}

Nutrient balances track the mass of nutrients added to and removed from a bounded system (fig. 1). The evaluated system scale can vary, including an individual field, whole farm, waterbody, watershed, county, state, sector, or an entire nation (Liu et al., 2020). Nutrient budgets are typically developed to provide insights into the rate of consumption and efficiency of use for a defined timeframe. However, many accounting systems use a time-step of one calendar or cropping year, although output can be reported for shorter or longer periods and source data can be compiled from datasets representing a wide range of durations. Compiling such metrics facilitates sustainable nutrient management by (1) tracking system performance over time, (2) assessing system dependency on a specific nutrient (elasticity), and (3) identifying opportunities to reduce nutrient losses.

In nutrient accounting methodologies, the term "balance" indicates the net surplus (accumulation) or deficiency (depletion) of the assessed nutrient within a defined area or system. A balance with no surplus or deficiency (zero) is extremely unlikely given the spatial and temporal variability of climate, soil, topography, and management practices in agricultural systems. Furthermore, the inherent variability in agricultural systems introduces a significant level of uncertainty that renders exact nutrient accounting practically impossible. Strategies such as proportional sampling, long-term monitoring, and data transparency can be used to address bias and uncertainty in the data sources used in budget development and incorporate this bias or uncertainty into the estimated balance (Oenema et al., 2003; Rufino et al., 2014; Zhang et al., 2021), improving the usefulness of the information gained. However, such efforts to improve data availability and quality are often constrained by cost and time limitations. Therefore, resources need to be allocated proportionally to minimize key

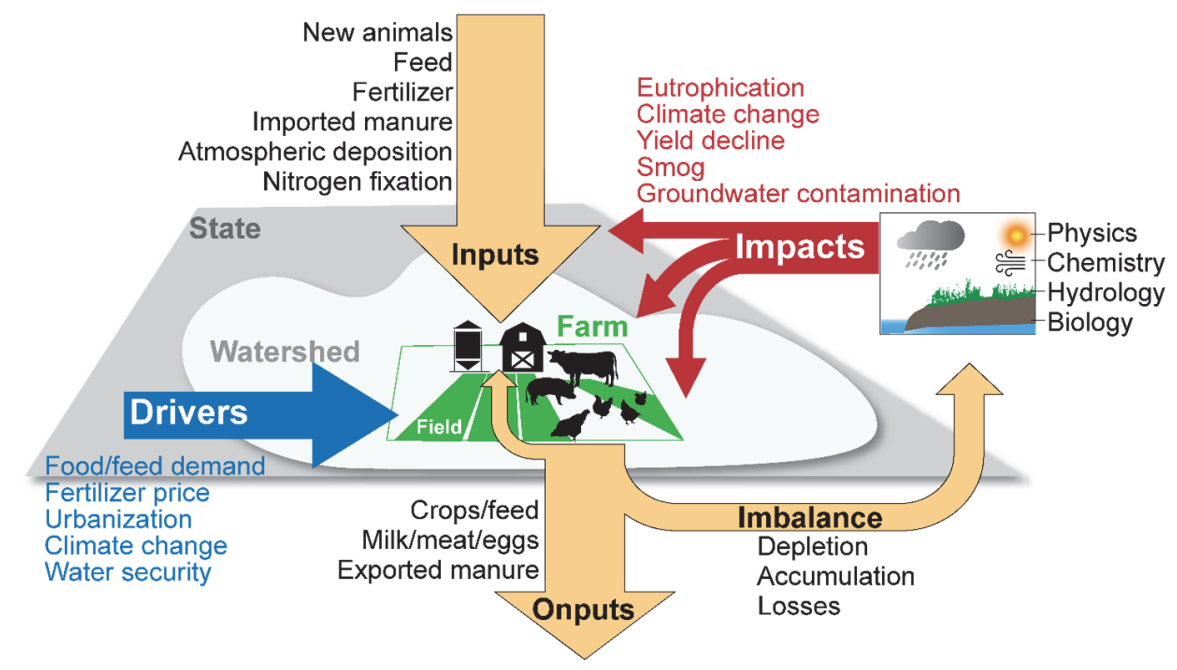

Figure 1. Conceptual diagram of animal food systems illustrating drivers, material flows, and impacts originating from and impacting different spatial scales (field, farm, watershed, and state). 
sources of uncertainty and bias in the overall balance estimation. Similarly, the level of detail (and correspondingly the uncertainty) is likely to change with changes in the spatial extent of the balance (scale). For a farm nutrient balance, tracking manure volumes generated and land-applied as well as sampling manures and soils for nutrient content are necessary datasets for developing the balance. In contrast, for a state-level balance, the contribution of manure is often captured from the number of animals of each species and a corresponding aggregate estimate of the annual manure excretion rate and nutrient content.

The quantitative outcome of this accounting provides little information about the state of the system at a specific moment in time. However, when benchmarked against similar systems or tracked over multiple years, the balance outcomes can provide insights into system performance and expected impacts due to the balance. These impacts can be immediately detectable (e.g., yield decline, crop stress), delayed (e.g., eutrophication, groundwater contamination), or transferred over a wider spatial scale (e.g., global climate change, estuary loss or degradation).

Delay in the onset of impacts from nutrient imbalance is a critical challenge that faces sustainable nutrient management efforts. Typically, localized and immediate impacts, such as yield declines, are prioritized over delayed and diffuse impacts, such as eutrophication and global climate change, primarily because the former have immediate economic consequences. For instance, nutrient oversupply as insurance against a yield decline associated with nutrient deficiency is a common example of this attitude (Sheriff, 2005). Osmond et al. (2015) found that university-recommended nutrient application rates are typically deprioritized by crop growers in favor of fertilizer dealer recommendations unless consistent and sustained one-on-one education is implemented at the watershed scale. Further evaluations are needed to guide policies and management practices to integrate immediate and delayed impacts.

Watershed or regional nutrient balances are useful tools to address these delayed and diffuse impacts of nutrient surpluses. The total maximum daily loading (TMDL) concept is an example of a watershed balance. Since the early 1990s, the U.S. EPA has implemented TMDLs to address water quality impairment (ASCE, 2017). This process identifies key drivers of impairment of a waterbody, defines the waterbody's assimilative capacity for the pollutants in question (nutrient, chemical, or sediment), and defines a pollutant load (TMDL) that attains and maintains water quality standards. In this process, the nutrient balance or budget is conducted around the water body to account for key contributing subwatersheds, or more specifically, attribute the nutrients to point sources (PS) or nonpoint sources (NPS). Sensitive ecological regions, such as the Chesapeake Bay region, have developed a deliberative process to identify key contributors of water quality degradation and identify priorities and mechanisms of action (environmental stewardship, nutrient trading, etc.).

County-based nutrient balances have drawn on these concepts, using crop and animal production data from the USDA Census of Agriculture, to identify nutrient-related risks in different geographic regions (Gollehon et al., 2001; Andersen et al., 2017). However, these balances are typically considered partial budgets or balances because they generally exclude synthetic fertilizer use and focus on biological nutrient cycling. Databases such as NuGIS (IPNI, 2012) strengthen abilities to consider synthetic fertilizers in nutrient balance approaches (Spiegel et al., 2020). Watershed-scale mass balances are the most recent effort to use the same mass balance methodology to identify water quality risks associated with nutrient imbalances due to animal manures and synthetic fertilizers. Unlike farm-scale tools that focus on nutrients used as embodied commodities, these approaches integrate accounting losses into the ecosystem as a first step toward integrating the delayed responses into mitigation strategies.

\section{Nutrient Balance Approaches}

The spatial scale of the study and the study goals influence the approach to nutrient balance development. For example, field-scale balances (fig. 2a) focus on nutrient applications and agronomic crop needs, where the sources of imbalance are excess fertilizer applications. In contrast, at the whole-farm or watershed scale, imbalances can result from many inputs and outputs, including animal feed and/or fertilizers brought into the farm or region in excess of the nutrient exports in animal products and harvested crops. As such, the methodologies for the nutrient budget will be different at varying spatial scales to accommodate the changes in inputs and outputs. For instance, at larger spatial scales, to account for nutrient flows through residential, industrial, and agricultural sectors, simplifications are often required at the expense of details for each sector (fig. 2c).

In addition, nutrient balance assessments can only inform management at the evaluated scale, so the intended goals must be clearly defined when selecting a scale and methodology (fig. 2 and table 1). In addition to the spatial scale and balance goals, data availability and the needs of the output users are important in selecting a methodology. A nutrient balance tool with fewer data requirements may be easier to implement by producers and possibly more useful than a complex, mechanistic nutrient balance methodology that relies on coefficients or factors to overcome data gaps for the farm system. An overall constraint is that the available data and methodologies for assessing the nutrient balance vary based on scale, as summarized in table 1.

\section{Field-SCAle Nutrient Balance}

Field-scale nutrient balances (fig. 2a and table 1) are generally developed to optimize crop yields, optimize nutrient use efficiency (NUE), and/or minimize nutrient losses (Dobermann, 2007). At this scale, a positive nutrient balance refers to an application of nutrients that exceeds crop uptake and increases the potential for environmental loss. Conversely, supplying nutrients at a lower rate than removed by the growing crop results in a negative balance, possibly reducing crop performance. A negative balance could also reduce the risk of nutrient transport via leaching, runoff, and/or erosion, assuming that sufficient plant growth is achieved to protect the soil and limit runoff. Data needs for field-scale nutrient balances are generally available at a reasonable level 


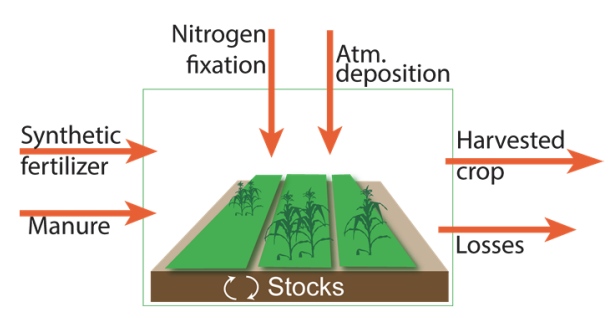

(a) Plant-soil system (field scale)

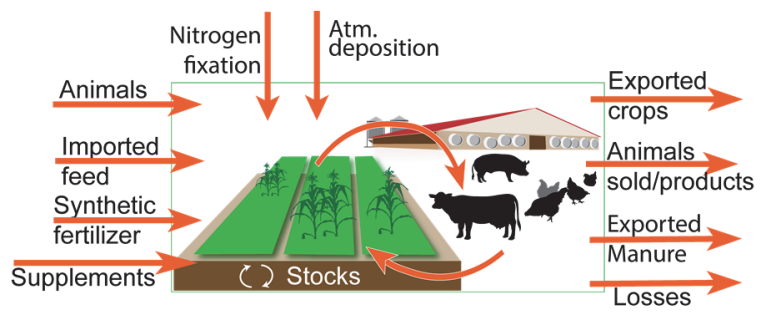

(b) Plant-soil-food animal system (whole farm)

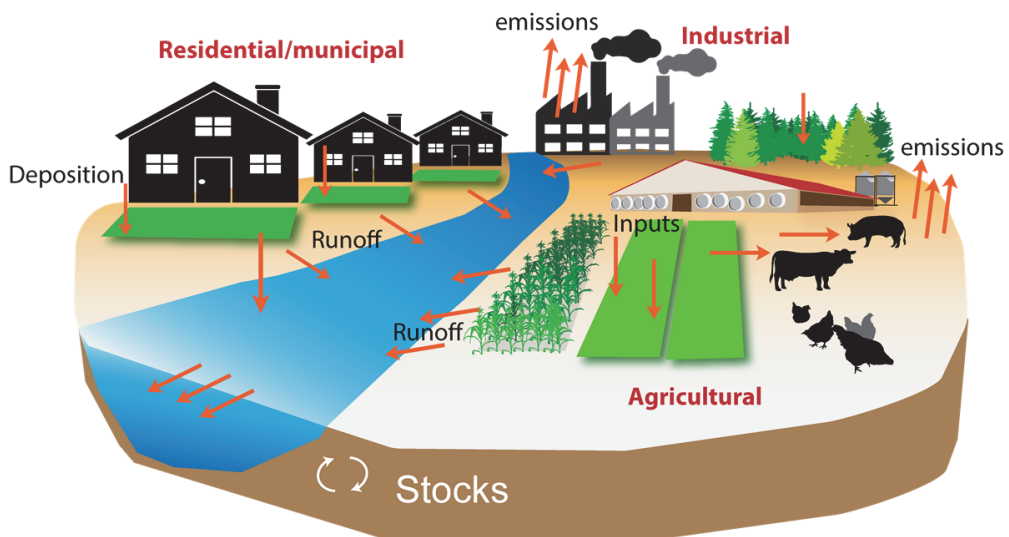

(c) Watershed or political boundary (with overlapping land-use sectors)

Figure 2. Nutrient balances at various scales.

Table 1. Summary of typical attributes associated with nutrient balances at four common scales along with an assessment of data quality.

\begin{tabular}{|c|c|c|c|c|}
\hline \multirow{3}{*}{$\overline{\text { Managed unit (scale) }}$} & \multicolumn{4}{|c|}{ Spatial Resolution } \\
\hline & \multirow{2}{*}{$\begin{array}{c}\text { Plant-Soil System } \\
\text { Field or subfield }\end{array}$} & \multirow{2}{*}{$\begin{array}{c}\text { Plant-Soil-Food Animal System } \\
\text { Whole farm }\end{array}$} & \multicolumn{2}{|c|}{ Mixed Land-Use System } \\
\hline & & & Watershed & $\begin{array}{l}\text { Regional political entity } \\
\text { (e.g., county) }\end{array}$ \\
\hline \multicolumn{5}{|c|}{ Data required (quality of available data) ${ }^{[a]}$} \\
\hline Inputs & $\begin{array}{l}\text { Fertilizer }(++) \\
\text { Manure }(+) \\
\text { Residual soil nutrients }(+) \\
\text { Nutrients from soil } \\
\quad \text { organic matter }(-) \\
\text { Biologically fixed } \\
\quad \text { nitrogen }(+)\end{array}$ & $\begin{array}{l}\text { Common: } \\
\text { Imported feeds }(++) \\
\text { Fertilizers }(++) \\
\text { Animals }(++) \\
\text { Possible: } \\
\text { Bedding purchases }(-) \\
\text { Legume fixed N (-) } \\
\text { Irrigation water } \mathrm{N}(+)\end{array}$ & $\begin{array}{l}\text { Fertilizer }(+) \\
\text { Manure }(+) \\
\text { Municipal wastewater } \\
\quad \text { and biosolids }(+) \\
\text { Imported feed }(+) \\
\text { Atmospheric } \\
\quad \text { deposition (-) } \\
\text { Nitrogen fixation (-) } \\
\text { Residual nutrients in } \\
\quad \text { agricultural soils (-) } \\
\end{array}$ & $\begin{array}{l}\text { Common: } \\
\text { Manure inputs } \\
\text { from confined } \\
\text { livestock }(+) \\
\text { Possible: } \\
\text { Inorganic } \\
\text { fertilizer } \\
\text { imported }(++)\end{array}$ \\
\hline$\overline{\text { Outputs }}$ & Crops harvested (++) & $\begin{array}{l}\text { Crops sold }(++) \\
\text { Animal products sold }(++) \\
\text { Manure transferred } \\
\quad \text { off-farm. }(+)\end{array}$ & $\begin{array}{l}\text { Crops (+) } \\
\text { Animal proteins }(+) \\
\text { Manure transferred }(+) \\
\text { Organic residue } \\
\quad \text { harvested }(-) \\
\end{array}$ & Crops harvested $(++)$ \\
\hline \multicolumn{5}{|l|}{ Commonly reported output } \\
\hline Nutrient balance & - & $\begin{array}{c}\text { +/- Balance amount per year } \\
\text { per farm, or input per } \\
\text { unit of output }\end{array}$ & $\begin{array}{l}+/ \text { - Balance amount per } \\
\text { year per watershed }\end{array}$ & $\begin{array}{l}+/ \text { - Balance amount per } \\
\text { year per county }\end{array}$ \\
\hline Nutrient use efficiency & $\begin{array}{l}\text { Unit of nutrient input per } \\
\text { unit of plant production }\end{array}$ & $\begin{array}{l}+/ \text { - Balance amount per unit } \\
\text { of animal production }\end{array}$ & - & - \\
\hline Nutrient intensity & $\begin{array}{c}\text { Unit nutrient input per } \\
\text { unit area }\end{array}$ & $\begin{array}{l}+/ \text { - Balance amount per unit } \\
\text { of cropland }\end{array}$ & - & - \\
\hline $\begin{array}{l}\text { dditional attributes } \\
\text { Typical nutrients }\end{array}$ & d phosp & are common. Additional nutri & could be assessed. & \\
\hline
\end{tabular}

of accuracy to the grower in the U.S. through historic yield estimations (USDA-NASS, 2021), yield monitoring and mapping (Fulton et al., 2018), along with locally available testing services for nutrient contents in soils, manures, and crops or forages.

Leveraging these data, several methods can be used to assess field-scale nutrient balances associated with targeted crop yields. For example, the yield goal method ensures an adequate nutrient supply to growing plants to achieve realistic crop yield goals. When the economics of fertilizers applied are coupled with yield expectations, as is common with $\mathrm{N}$, this is referred to as economically optimal $\mathrm{N}$ rates (EONR) (Morris et al., 2018). Several studies have pointed out that applying $\mathrm{N}$ at EONR can achieve economic 
profitability and support environmental stewardship goals by reducing residual soil nitrate (Bélanger et al., 2003; Hong et al., 2007). In a comparison between $\mathrm{N}$ rate recommendation tools across U.S. Midwest states, the yield goal methods was found to result in the greatest environmental cost associated with $\mathrm{NO}_{3}-\mathrm{N}$ losses, with most tools having comparable economic performance (Ransom et al., 2020). While the methods used for field-scale nutrient balances generally lead to less residual nutrients in the field, their typical one-year outlook does not serve to rectify imbalances over time. Nutrient management plans (NMPs) are commonly used to evaluate field-scale nutrient balances over consecutive years. NMPs generally include adjusting manure application rates to meet crop requirements from either nitrogen $(\mathrm{N})$ or phosphorus (P) and avoid over-application (USDA-NRCS, 2019) and relying on supplemental nutrient forms to address any deficient nutrients.

Efforts to encourage field-scale nutrient balancing are integral to U.S. federal and state conservation policy. A fieldscale nutrient balance is a component of the comprehensive NMP (CNMP) process, established by the USDA-NRCS, in which soil nutrient levels, as well as the fertilizer applied in each field, are evaluated against crop nutrient uptake. In addition, NRCS nutrient management efforts promote adopting the right nutrient source, right application rate, right timing, and right placement (referred to as the 4Rs) to meet crop demand while minimizing potential loss to the environment (USDA-NRCS, 2019). In animal agriculture, the role of manure nutrients, particularly in large animal feeding operations (AFOs), has been recognized in both national and state regulatory frameworks (USEPA, 2020). A CAFO designation under U.S. EPA policy typically requires implementing an NMP that includes field-scale balances for fields associated with a CAFO (USEPA, 2020). NMPs account for nutrient application from manure and fertilizers on a field-byfield basis to ensure that nutrients are used beneficially (Centner and Newton, 2011). Comparing multiple fields is an example action that adds to decision-making and, potentially, corrective action.

However, even if multiple years are considered, there are many circumstances in which fertilizers are applied in excess of the agronomic recommendations to protect against yield losses. In addition, the ratios of nutrients in manure fertilizers are rarely a perfect match for all crop needs, so over-application of some nutrients can occur when targeting a specific nutrient to define the application rate needed to reach a target goal. Variable-rate application (VRA) of nutrients and site-specific soil sampling can reduce variability in sub-field soil nutrient balances compared to conventional fixed-rate application methods (Mallarino and Wittry, 2010). Further technological advances in precision farming using spectral analysis to increase the accuracy and precision of manure nutrient applications have potential to further reduce soil nutrient variability (Williams et al., 2020). Integrating these systems with nutrient management plans has potential to further improve the accuracy and use of field-scale nutrient balances.

Modifications and adaptions of these methods over time have attempted to reduce environmental risk. For example, because many $\mathrm{N}$-based manure applications result in excess
$\mathrm{P}$ applications, a $\mathrm{P}$ index tool was integrated into many CNMP systems to reduce the risk associated with $\mathrm{P}$ loss. This index is a field-scale method for identifying lower-risk fields for storage of excess soil $P$ that cannot be corrected in the short-term (Sims, 1993). These types of modifications attempt to address nutrient balance issues for multiple nutrients at the field scale. Advancements in nutrient application methods, accounting practices, and software capabilities continue to improve field-scale nutrient balance assessment systems. However, because many environmental impacts are realized at a larger scale, there is need for nutrient balance assessment systems at a comparable spatial scale.

\section{WHOLE-FARM NUTRIENT BALANCE}

Whole-farm nutrient balances involve managing nutrient inputs and outputs at the farm level (fig. 2b). Whole-farm nutrient balances aim to determine whether the farm has nutrient accumulation or depletion, as well as the driving forces contributing to the imbalances to aid management at the farm level. Whole-farm nutrient balances provide insights into nutrient drivers, farm-level NUE, emerging challenges, and potential opportunities for corrective action. Wholefarm balances typically measure nutrient inputs such as animal feed, fertilizer, bedding, legume fixed $\mathrm{N}$, and nutrients in irrigation water. Exports from whole-farm balances include managed products such as meat, milk, exported crops, and manure transported off-farm. Farm-level measures can attempt to estimate losses to the environment or nutrients accumulating within the boundaries of the farm; however, this is not present in all evaluations. Internal nutrient flows within the farm's boundaries can provide useful insights because the efficiency of these flows influences the magnitude of the nutrients imported and losses to the environment.

An integrated whole-farm approach allows comparison of options for both animal and crop nutrient management (Dou et al., 1998) as well as a means of evaluating the environmental performance resulting from alternative nutrient management strategies (Koelsch, 2005; Frink, 1969; Aarts et al., 1992; Lanyon and Beegle, 1993; Klausner, 1995; Watts et al., 1994). Whole-farm nutrient balances have been applied to the dairy industry (Histov et al., 2006; Cela et al., 2014b; Spears et al., 2003a, 2003b; Kettering et al., 2012), as well as swine (Koelsch, 2005), beef (Smolen et al., 1994; Watts et al., 1994; Koelsch and Lesoing, 1999), and poultry (Smolen et al., 1994). An example of a modeling tool used to facilitate whole-farm nutrient balances is the Integrated Farm System Model (IFSM). IFSM is a process-based model that captures crop and pasture production, farm operations, manure handling, and economics (Rotz, 2012). The model develops multi-year, whole-farm balances of $\mathrm{N}, \mathrm{P}, \mathrm{K}$, and $\mathrm{C}$ through predicting water and airborne losses from the integrated crop and livestock system. Most studies that reported using this model were applied to beef and dairy farming systems (Waldrip et al., 2014; Bonificio et al., 2015).

A whole-farm approach provides additional insights and opportunities to improve nutrient use through optimized feed formulation, alternative crop rotations, and manure export. Federal U.S. public policy has not engaged this approach for farm nutrient management, but state-based initiatives have emerged recently in New York, Virginia, Pennsylvania, and 
California, primarily for dairy production (Cela et al., 2014a; Pearce and Maguire, 2020; Holly et al., 2019; Miller et al., 2017). Promising impacts from example initiatives are discussed in detail in a later section of this article.

\section{REGIONAL OR WATERSHED NUTRIENT BALANCE}

A nutrient balance for a watershed or larger spatial unit quantifies the nutrient inputs and outputs across multiple land uses, beyond the individual field or farm level. These balances are often established to screen for a causative link between land uses, nutrient sources, and management practices, as well as the loading of nutrients to water systems or air emissions. Inputs can include fertilizer, manure, imported feed, and atmospheric deposition, as well as potential sources such as industrial or municipal wastewater treatment residues (e.g., sludge) and other nutrient sources from both agricultural and other land uses. Correspondingly, nutrient outputs for a larger area can include harvested crops, protein, manure exports, and food products. While produced animal protein (meat, milk, and eggs) is a form of nutrient export, it is often secondary to nutrient budgets targeting soil-water interactions, unless quantifying the NUE of animal production systems is the goal.

The magnitude of surplus in nutrient balances is typically used as a predictor of nutrient loss, with the goal of using these balances to guide allocation of resource for intervention to address the imbalance. However, nutrient balances alone are insufficient to explicate nutrient transport mechanisms, which rely on spatially and temporally explicit interactions between land use, climate, soil type, and management practices. Nutrient budgeting for $\mathrm{N}$ and $\mathrm{P}$ across 68 watersheds in Iowa showed that manure $\mathrm{N}$ and $\mathrm{P}$ accounted for $13 \%$ and $45 \%$ of statewide inputs, respectively, while manure $\mathrm{N}$ volatilization accounted for $6 \%$ of $\mathrm{N}$ outputs (Libra et al., 2004). In the same study, watershed $\mathrm{N}$ loading was found to correlate with the share of row crops in the watershed and with $\mathrm{N}$ fertilizer and manure inputs. Budget-loading relationships for $\mathrm{P}$ were less clear, likely due to the larger role that soils play in mediating $\mathrm{P}$ transport. Soil regulates nutrient movement by acting as a source through mineralization, volatilization, and erosion, as well as a nutrient sink via storage and immobilization. In their study of the relationship between $P$ inputs and loading to riverine systems across the U.S., Metson et al. (2017) suggested that excluding the role of legacy soil P may have resulted in a weaker relationship between $P$ inputs and riverine exports. In their study of nutrient inputs to northeastern U.S. from 1930 to 2000, Hale et al. (2013) suggested that cumulative P inputs are better predictors of $\mathrm{P}$ loading than annual $\mathrm{P}$ inputs. In a watershed modeling study of the Maumee River watershed, soil P contributed between $39 \%$ and $49 \%$ of total annual P (Kast et al., 2021). These observations suggest that in the absence of explicit soil analysis data, reconstructing historical nutrient balances for a region might be particularly useful in ranking regions for intervention to address water quality challenges.

The primary data sources for such scales are administrative data products. In the U.S., a quinquennial Census of Agriculture (COA) is conducted by the USDA National Agricultural Statistics Service to compile a count of agricultural operations, products, and operators (USDA-NASS, 2019).
In this census, system components that can be used as inputs in nutrient balances (e.g., cropped acres, fertilizer consumption) are inventoried, as well as potential outputs such as finished animals and harvested crops. The finest spatial resolution for USDA census data is county-level. Several countylevel partial nutrient balances were published using USDA census data (Gollehon et al., 2001; Andersen et al., 2017; Swink et al., 2011). These balances typically compare manure nutrients within a county using USDA county animal numbers and corresponding manure characteristics to estimate inputs to county cropland. Nutrients harvested by crops within a county (exports from county cropland) are typically estimated using acreage, yield, and nutrient concentration in each grown crop.

Partial nutrient balances are relatively easy to compile and can facilitate comparisons between counties in terms of their potential for manure-driven imbalances. In practice, however, county-based balances do not capture the density of production within a county. This is primarily due to the averaging effect of summing nutrient inputs and outputs across a larger spatial unit. A U.S. partial nutrient balance study concluded that while a small share of counties (205 of approximately 3,070 counties included in the Census of Agriculture database) have county-level excess manure, their number has increased over time (Gollehon et al., 2012). To assess farm-level nutrient balances, Gollehon et al. (2012) relied on a simulation model to assign locations for AFOs within each county and assign acres as local to farm and potential acres for manure export. However, it is important to note that these partial nutrients balances do not account for other nutrient sources, which may significantly impact the overall nutrient balance in a given area.

Developing regional nutrient balances based on spatial resolutions finer than county-level requires additional data or modeling. For agricultural components, the most basic data needs include the location and size of individual animal operations, the location and size of fields, the cropping rotation in each field, and the consumption rates of external sources such imported feed and synthetic fertilizer. The data overhead associated with this effort is significant and might not be possible due to proprietary considerations. Alternative approaches to overcome data limitations rely on models for manure hauling distances such as manure break-even distance or assumptions specific to the region (Araji et al., 2001; Porter and James, 2020). Spiegal et al. (2020) assessed each U.S. county as either a source or sink for AFO nutrients. They proposed the concept of "manureshed" to describe counties that could potentially assimilate AFO nutrients from adjacent source counties. Their study identified four manuresheds across the U.S. (i.e., the Carolinas, Puget Sound, Southern Plains, and Interior Highlands), which represent contiguous counties with significant surplus manure nutrients that require coordinated regional planning and management to address.

\section{ACTION THRESHOLDS AND STRATEGIES FOR NUTRIENT BALANCE IMPROVEMENT}

After conducting a nutrient balance using any of the three previously discussed approaches, it is important to explicitly identify the threshold that requires action. The threshold for 
action describes a quantitative limit at which the results of a nutrient balance analysis indicate a need to implement actions to improve the balance. Thresholds for action at each scale should include a timeframe for the assessment and an additional timeframe to reach a specific target (e.g., the date when nutrient inputs meet a specified level of productivity). Multi-year tracking or averaging may be necessary due to data variability. Nutrient balances ideally account for the delay (lag) between management decisions that affect the nutrient flows, nutrient buildup, and undesirable flows across the field or farm boundary and the time when the results of these decisions start appearing in the watershed, river basin, or groundwater. The lag periods associated with this dynamic process increase as the spatial scale of the balance increases. The threshold for action should provide a standard, beyond expected system variability and inherent uncertainty in the data and results, for which it is generally known that exceeding the threshold value results in adverse economic or environmental impacts.

\section{Field-Scale Nutrient Balance}

Field-scale nutrient balance analysis is gaining favor as a conveniently calculated measure with acceptable thresholds for action. McLellan et al. (2018) described thresholds for action for field $\mathrm{N}$ balances, as shown in figure 3. A comparison of $\mathrm{N}$ inputs versus $\mathrm{N}$ harvested (or NUE) provides an indication of a safe operating range that protects both yield potential and water quality. McLellan et al. (2018) encouraged use of readily available data for estimating NUE. They suggested that this approach could serve as a suitable measure to benchmark current practices and provide a threshold for encouraging improved management of $\mathrm{N}$.

Field-scale balances, including NUE monitoring, encourage improved nutrient management by farmers that targets efficient matching of nutrient inputs and outputs in time and space for an individual field (McLellan et al., 2018). Nutrient balances found to be outside the safe operating range encourage strategies and practices for improving NUE to achieve both food production and environmental protection goals. Morris et al. (2018) summarized strategies for $\mathrm{N}$ recommendations in crop production, a critical component of $\mathrm{N}$ fertility product management. Similarly, Sharpley et al (2009) compiled field-level $\mathrm{P}$ loss recommendations, noting that approximately $80 \%$ of $\mathrm{P}$ losses originate from hot-spots $(\sim 20 \%$ of the area), which necessitate site-specific management.

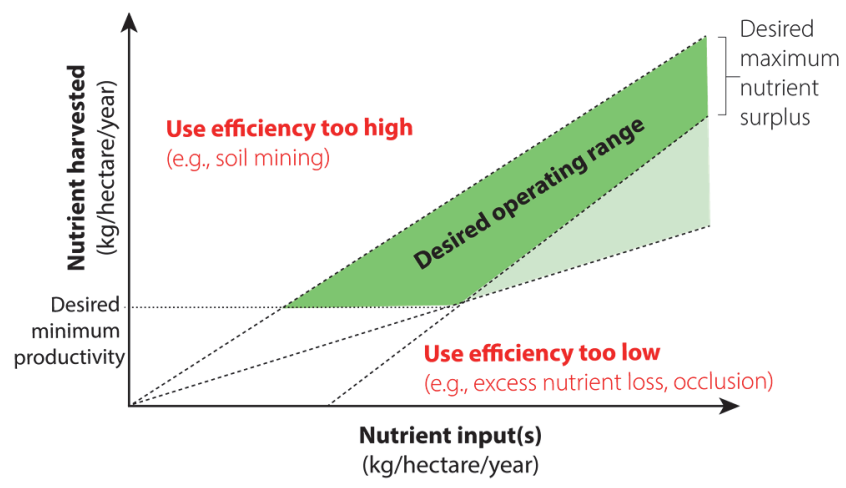

Figure 3. Illustration of a safe operating range and introduction of a threshold for action based on a comparison of nutrient harvested to nutrient input (adapted from McLellan et al., 2018).
Most current strategies for improving field-scale nutrient balances relate to the 4Rs of nutrient stewardship (Bruulsema, 2009). Additionally, there are region-specific recommendations that encourage specific practices, such as split and in-season fertility application, research-based nutrient application rates, and site-specific precision application of fertility products (Sitthaphanit et al., 2009). Fertility recommendations from land grant universities provide a foundation for strategies that will improve field-scale nutrient balances.

Efficient conversion of organic nutrients into food, feed, and fiber and the resulting improvements in field-scale nutrient balances will be further assisted by producers' adoption of technology innovations. For example:

- Processing of manures and organic by-products results in products with nutrient concentration ratios that can better meet crop demands, are easier to handle, and have less risk from pathogens (e.g., pelletized manure) (Liu et al., 2016).

- Precision manure application technologies can ensure desired application rates and variable rates to meet site-specific yield goals.

- Technology innovations to densify manure nutrients to increase the economically feasible hauling distance from an AFO can reduce excess nutrient applications and engage more crop production in the recycling of nutrients (Sharara et al., 2018; Sampat et al., 2019).

The value of strategies targeting field-scale nutrient balances results from:

- Targeting of decisions made specifically by crop farmers and their network or advisors and consultants.

- Targeting of approaches that have a strong foundation in research and field experience for demonstrating value.

- Encouraging efficient manure nutrient recycling in agricultural systems.

\section{Whole-Farm Nutrient Balance}

At the whole-farm scale, excess nutrients are commonly driven by imported animal feeds, with fertilizer imports typically representing a small component of the nutrient input (fig. 4). However, not all balance components are measurable on-farm (i.e., aerial emissions; waterborne losses). Cornell University's nutrient team has collected extensive data for whole-farm nutrient balances over +15 years to identify acceptable operating ranges for dairy farms (Cela et al., 2014b, 2015), which account for reasonable losses that are not measured. Cornell's nutrient team proposed a feasible operating range or a threshold for action based on wholefarm nutrient balances. The threshold reflects a nutrient imbalance relative to area, i.e., $\leq 118 \mathrm{~kg} \mathrm{~N}$ per ha $\left(105 \mathrm{lbs} \mathrm{ac}^{-1}\right)$ and $\leq 13 \mathrm{~kg}$ P per ha (12 $\left.\mathrm{lbs} \mathrm{ac}^{-1}\right)$, and relative to milk production ( $\leq 8.8 \mathrm{~kg} \mathrm{~N} \mathrm{Mg}^{-1}$ of milk and $\leq 1.1 \mathrm{~kg} \mathrm{P} \mathrm{Mg}^{-1}$ of milk). To date, these whole-farm nutrient balances are promoted primarily for farmer applications and not for public policy decisions. While this is only one example of potential farmscale thresholds for action, there is need to identify and 

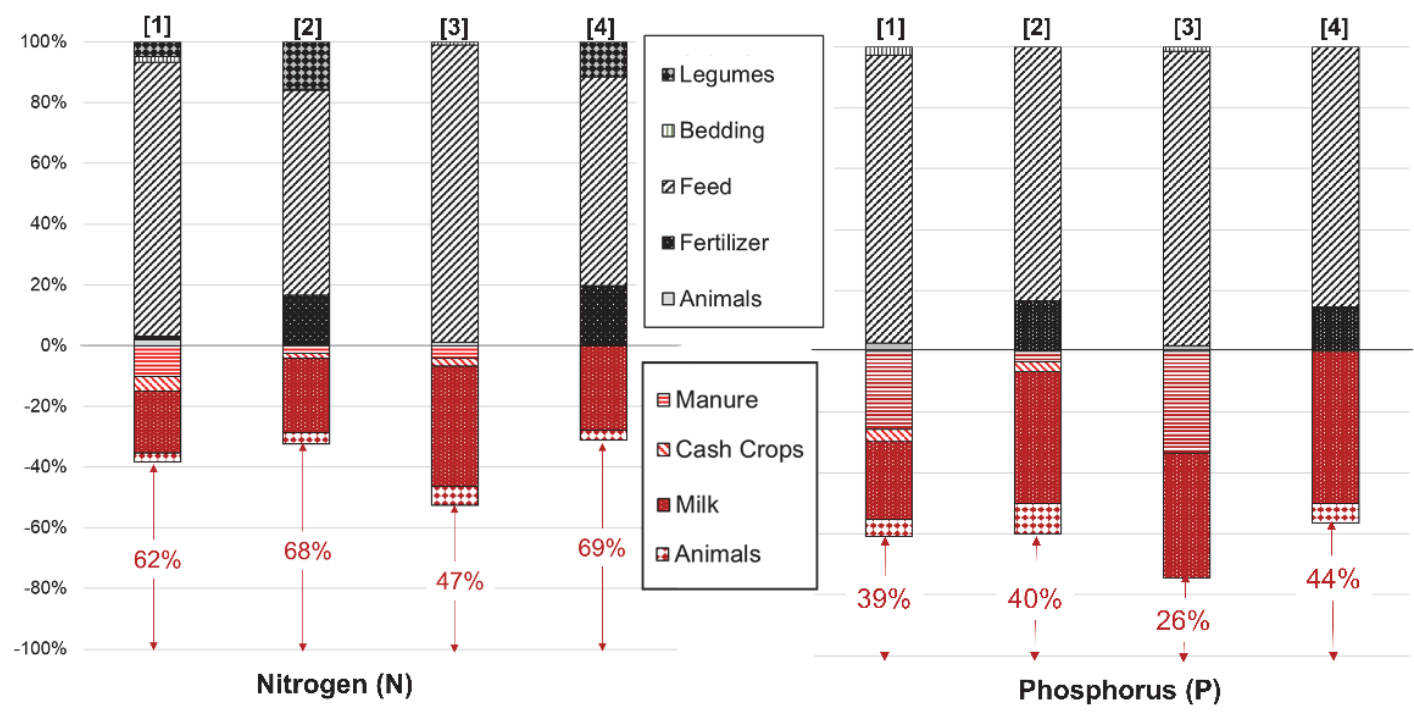

Figure 4. Nitrogen and phosphorus flows in dairy farm inputs and outputs (as a share of total inputs) at a single time-point: [1] = Histov et al. (2006), $[2]$ = Cela et al. (2014b), [3] = Spears et al. (2003b), and [4] = Cela et al. (2014b). Farm inputs are shown in black, farm outputs are shown in red, and red arrows represent the magnitude of the imbalance (accumulation) as a ratio of total farm inputs.

examine other thresholds for other regions of the U.S. and other species.

Soberon et al. (2015) described an eight-year period for a New York dairy farm (640 cows) during which the farm increased its land base and reduced its use of imported fertilizer nutrients and animal feeds. The reduction in imported feed proved the most valuable change for achieving a feasible P balance (fig. 5). Kettering (2014) discussed examples of implementing an adaptive approach to nutrient management by New York dairy farms resulting from whole-farm balance monitoring and reflected on the key ingredients for a successful adaptive approach to management of nutrient resources. While economic efficiencies helped propel the nutrient balance changes reported by Soberon et al (2015), the cost-benefit ratio may not always be favorable.

In a review by Koelsch and Kettering (2017), the researchers identified several practices that showed significant progress for improving nutrient imbalances in dairy systems. The list is applicable to other systems:

- Manure export: Larger AFOs with a limited land base have made improvements in their nutrient balances by exporting manure to an outside party, such as a neighboring crop farm or manure brokers. When most feed nutrients originate from off-farm sources, recycling nutrients within the AFO's land base is not practical.

- Increasing arable land access: Adding land will benefit the whole-farm balance if it reduces the need to purchase feeds and provided additional options for manure nutrient recycling on land under the AFO's control.

- Reducing imported feed: Imported feed is commonly the single largest source of nutrients arriving on farms. Options often exist for improving feed use efficiency, reducing feed storage losses, and moving some animals (and their feed requirements) to alternative sites.

The value of strategies targeting whole-farm nutrient balances results from:

- Recognizing the role of imported feed as a critical driver behind excess nutrients on many farms. This includes engaging feed strategy decision-makers to recognize the impacts of their decisions on the farm and regional nutrient concentrations.

- Encouraging planning around the total land area (owned by the AFO and accessed through manure

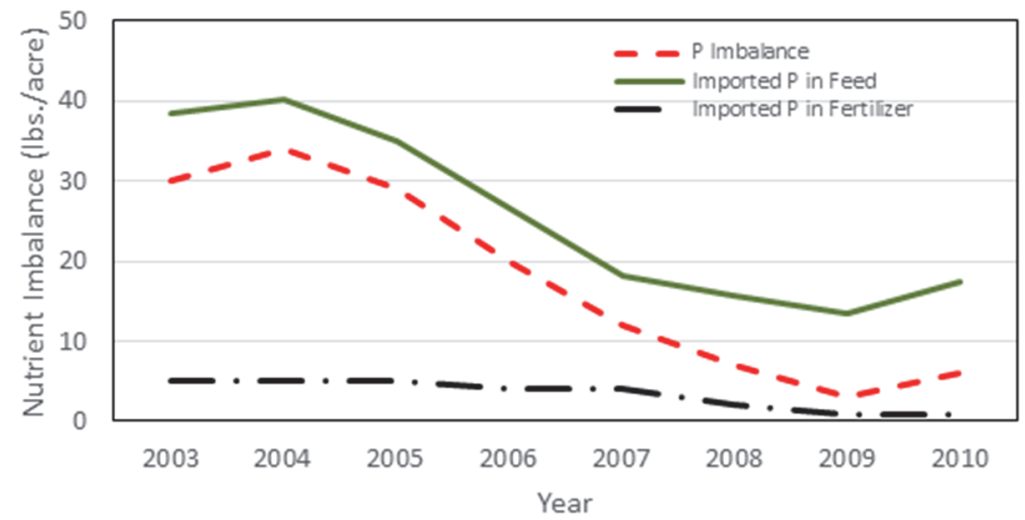

Figure 5. Improvements in whole-farm nutrient balance over eight years due to reduced imported feed and fertilizer (Soberon et al., 2015). 
transfer) required for managing manure nutrients produced by an AFO.

- Recognizing that AFOs importing significant feed nutrient resources will need to export manure nutrients to other crop farms to achieve reasonable farm balances.

While these practices are primarily associated with individual producers, the wider agricultural community, along with conservation and regulatory agencies, play a major role in demonstrating the impact of these practices and providing resources, through cost-share and agreements, to encourage management changes.

However, manure storage and treatment contribute a significant share of nitrogen losses, prior to land application, as gaseous emissions. Ni et al. (2018) estimated that $56 \%$ of manure nitrogen from swine systems is in the form of ammonia, with 30\% lost from swine houses and 25\% lost from manure management and land application. Similarly, Hirstov et al. (2011) estimated that between $25 \%$ and $50 \%$ of nitrogen in cattle and dairy manure is lost as ammonia nitrogen.

In addition to the role of ammonia in particulate matter formation, its deposition contributes to nutrient accumulation in the surrounding landscape. Shen et al (2016) estimated that $8.1 \%$ of annual ammonia emissions from a beef lot were deposited within $1 \mathrm{~km}$ of the feedlot. Conserving these emissions through diet modification (Ferket et al., 2002), acidification (Cao et al., 2020), and manure covers is critical to address this significant nutrient loss pathway. As adoption of these practices increases, CAFOs, particularly in high-density regions, are likely to encounter challenges in locating sufficient land nearby to use their conserved nutrients beneficially. Establishing a wide network that connects nutrient sources and sinks beyond the immediate geography will be critical to address this challenge.

\section{Regional or Watershed Nutrient Balance}

Interest in nutrient management improvements to address nutrient-related pollution is often tied to surface and groundwater quality (Howarth et al., 2002; Shortle and Horan, 2017) as well as airborne nutrient emissions such as $\mathrm{NH}_{3}-\mathrm{N}$. These impacts are closely connected to health, economic, and social impacts on the affected communities (Dodds et al., 2009; Domingo et al., 2021). This discussion focuses on nutrient impacts on water quality. Waterborne nutrients transported across basins and landscapes can trigger water quality impairments across large extents of water resources (Robertson and Saad, 2021). Currently, classifying a waterbody as impaired, according to Section 303(d) of the Clean Water Act, is the trigger for action to remedy the impairment. The classification is often performed by states or tribes, and it links a contaminant, or contaminants, to the observed impairment. Based on this designation, a TMDL plan is developed. Despite several critiques of the classification criteria (Keller and Cavallaro, 2008), TMDLs are the current acceptable threshold for action at the watershed or river basin level. Efforts to address water quality in a watershed or basin involve monitoring and modeling efforts, including nutrient balance development, to identify sources and their contributions (point source vs. nonpoint source) and key transport pathways to the waterbody (Ohio EPA, 2018; Kast et al., 2021). Adopting mitigation strategies to meet TMDL goals can be challenging, as evidenced by efforts in the Chesapeake Bay region (Kleinman et al., 2019), where cropping and animal production play a major role in $\mathrm{P}$ export, as sediment or dissolved $\mathrm{P}$, to the bay.

County and region-based nutrient balances have identified U.S. regions where manure nutrients produced locally exceed the assimilative capacity of local arable land (Barker and Zublena, 1995; Kellogg et al., 2000; Spiegal et al., 2020). These regions are likely to play a larger role in nutrient export to nearby aquatic systems (Sabo et al., 2019), although the variability in regional buffer capacities is likely to increase the variability in response to legacy nutrients across regions (Stackpoole et al., 2019). Considering locally produced manure nutrients in addition to commercial fertilizer use is an essential step for identifying regions that can benefit from manure redistribution and export programs (Spiegal et al., 2020). Thresholds based on a region's ratio of fertilizer and manure inputs relative to its cropland resources may provide a useful tool for public policy interventions to encourage nutrient trading or taxing or zoning policies that encourage or discourage future livestock expansion.

Although beneficial, proposing a safe operating zone for nutrient use in a watershed, or a larger region, can be challenging. This is primarily due to the significant time and cost associated with the development and validation of a safe operating zone and the potential resistance to adoption, particularly in cases where the available actions incur economic costs or losses. In many cases, regional imbalances have taken years to develop, and neither field-scale nor wholefarm interventions are sufficient to undo the water quality impacts. In these cases, more responsibility falls on local leaders to adapt strategies at a scale commensurate with the challenge, such as the watershed. The primary objectives of a regional balance are (1) identifying and prioritizing nutrient sources within the region over imported sources, primarily feed and fertilizers, to approach balancing, and (2) determining whether nutrient accumulation in the region exceeds the region's nutrient assimilation potential, and thereby demonstrating the value of transferring nutrients outside the region.

Table 2 summarizes common methodologies used to develop nutrient balances at varying scales along with their potential utility to inform water quality improvement efforts. Regional measures of nutrient balance are likely to inform redistribution strategies, such as:

- Nutrient trading schemes, including accounting methodologies, that prioritize regions with nutrient surpluses.

- Development and standardization of marketable nutrient products to facilitate transport of manure nutrients over longer distances.

- Developing policies that account for the costs associated with the increased environmental impact resulting from the nutrient imbalance.

- Nutrient tax structures to incentivize the use of recycled nutrients (e.g., manure) over imported fertilizers to reduce imported nutrients.

- Smart technology strategies, such as continuous measurement of manure nutrient concentrations 
Table 2. Summary of common nutrient balance methods and their suitability for use in farm or policy-based decisions to improve water quality.

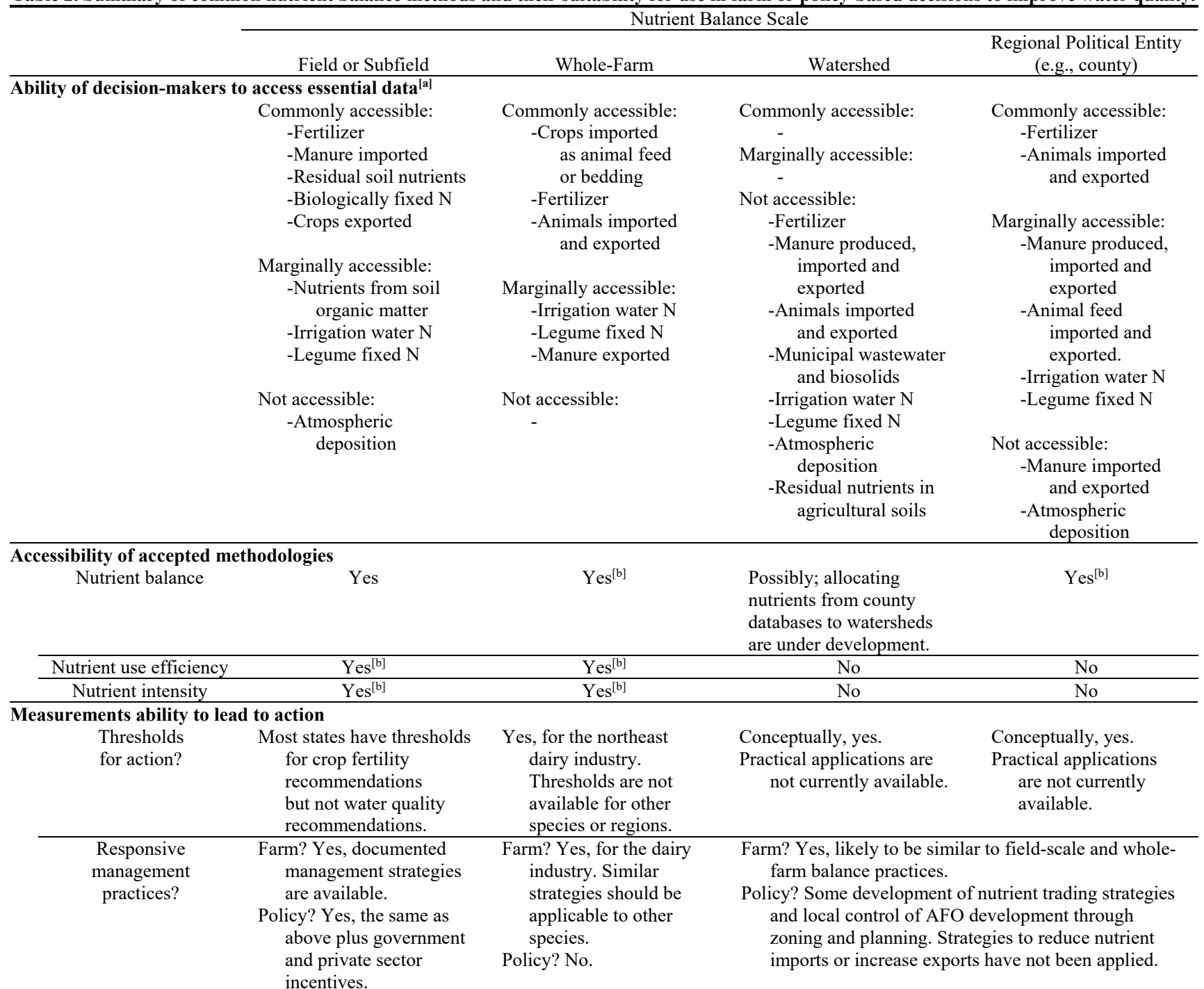

[a] Fertilizer = inorganic fertilizer imported across the boundary of the nutrient balance.

Manure $=$ organic nutrient sources including manure imported or exported across the boundary of the nutrient balance.

Crops $=$ grains, forages, and other biomass imported or exported across the boundary of the nutrient balance.

Animals = immature animals imported for replacement or finishing, mature animals exported, and mortalities rendered off-site.

[b] Used primarily in research or academic settings.

during land application, will improve the reporting of nutrient application and the transfer of manure nutrients to more distant fields.

The success of many of these strategies depends on establishing collaboration structures that engage producers, regulatory agencies, and communities with research and conservation agencies. These collaborations are critical to understand the barriers and establish realistic goals and benchmarks (Deviney et al., 2021).

\section{RECOMMENDATIONS FOR SCIENTIFIC CONTRIBUTIONS TO NUTRIENT BALANCES}

Nutrient balances for whole-farm or regional/watershed scales provide a unique opportunity to reduce the environmental risks associated with nutrient use in integrated agricultural systems involving significant animal production. While the historical focus on field-scale nutrient balances has improved nutrient management in these systems, field-scale nutrient planning is not a comprehensive solution to sustainable nutrient management. Whole-farm and regional/watershed-scale nutrient planning processes will be critical to improved nutrient management decisions by AFOs and public policy-makers. At all scales, there remains room for the scientific community to refine, improve, and design processes. In the following sections, recommendations are outlined to assist in the development of these nutrient balance concepts.

\section{KNOWLEDGE EXCHANGE WITHIN THE SCIENTIFIC COMMUNITY}

Convening a series of workshops on the state of science around the topic of nutrient balances for whole-farm and 
regional scales is recommended. Such workshops can accomplish the following:

- Define the rationale for each of the three scales of nutrient balance.

- Summarize current knowledge and future opportunities for advancing both research and practical applications.

- Establish methodologies and thresholds for action for whole-farm and regional/watershed scale nutrient balance applications.

These workshops need broad participation from academic and stakeholder organizations to ensure the relevancy of nutrient balances among animal industry and public policy sectors.

\section{SCIENTIFIC RESEARCH}

Research communities should target one or more of the following opportunities to enhance the application of nutrient balance concepts.

\section{Data Availability}

Data on synthetic fertilizer use are a priority need to get a complete picture of nutrient cycling at regional or watershed scales. Such data are typically compiled by federal or state agencies but often at a low spatial resolution (e.g., state level). The Nutrient Use Geographic Information System (NuGIS) is an example of such effort, which provides county-level estimates of nutrients from manure and fertilizers (INPI, 2012). In the NuGIS database, fertilizer use data rely on sales data provided to the Association of American Plant Food Control Officials (AAPFCO). The data availability varies between states from county-level to state-level. In addition, because multi-county fertilizer distributors do not allocate sales among their served counties, relying on reported county-level sales does not provide an accurate estimation of fertilizer nutrient use (Ruddy, 2006).

It is recommended that research groups engage regional groups and authorities to develop transparent data collection strategies for synthetic fertilizer use. Surveys of synthetic fertilizer use are critical for a complete picture of nutrient use because data on sales alone do not solely describe nutrient cycling. Similarly, high-resolution data on manure composition, application rates, and corresponding yields are not typically shared. There is a need to devise a strategy to facilitate data sharing without compromising established relationships between researchers and producers or stakeholders in the region. Multi-state efforts to aggregate such analysis datasets, after anonymizing and aggregating to watershed or county level, would greatly assist modelers in developing more representative nutrient use scenarios while protecting AFO data privacy.

\section{Modeling Assumptions}

For larger spatial units such as watersheds, basins, and counties, certain assumptions are necessary for developing nutrient balances. For instance, the rate of fertilizer consumption on individual farms or fields is often assumed based on the total state fertilizer consumption. Similarly, assumptions are required to model livestock production where each land unit (field) is allocated to a singular livestock operation. Such assumptions are inevitable due to the lack of publicly available detailed records of fertilizer use, land ownership or rent, and the varying types of arrangements between crop growers and livestock producers. These assumptions can significantly affect the modeling results and reduce the utility of such studies. There is a need for an intentional and transparent model development process in which sensitivity analysis is conducted for key study assumptions and stakeholder inputs are engaged for the development of these assumptions.

\section{Integrating Field and Farm Balances with Regional Balances}

While nutrient balances compiled at different spatial scales have different objectives, there is an opportunity to provide continuity in nutrient use improvements by integrating these balances. This integration can be developed through a computational framework that aggregates finer balances into a larger regional balance. Such a framework can be maintained by regional authorities or cooperatives to maintain user data privacy while allowing modeling activities to identify opportunities for improving nutrient management.

\section{Precision Agriculture}

New technologies that improve fertilizer and manure application rate, timing, and placement of the nutrients used in crop and animal production create the opportunity for substantial improvements in nutrient and manure management. These emerging technologies will support precision management of manure in crop production, precision feeding of animals, and improved tracking of nutrient flows in agriculture. Their ability to lead to improved nutrient balance will need to be evaluated and maximized.

\section{APPLiCATION RECOMMENDATIONS}

Implementation of nutrient balance methodologies will require specific actions to encourage adoption. The following recommendations target expanded implementation of these nutrient-planning processes at the three proposed scales.

\section{Field Scale}

- Develop a national aggregated manure analysis database benchmarking manure nutrient concentration and availability by species, region, and production system;

- Apply precision management technology implementation for manure management as a crop fertility product.

\section{Whole-Farm Scale}

- Develop a recommended methodology for commercial farm application of whole-farm nutrient balances across animal species. The initiatives adopted by the dairy industry in New York provide a good example for this methodology development and implementation.

- Develop region- and species-specific benchmarks for whole-farm nutrient balance to guide management. 
These benchmarks will serve as thresholds for recommending alternative management strategies.

- Engage with industry efforts leading industry sustainability measurement (e.g., U.S. Roundtable for Sustainable Beef) and evaluate the role of farm-scale nutrient balance.

\section{Regional Scale}

- Engage regional and local entities guiding decisions for spatial planning of future animal industry expansion and contraction in applying regional- and watershed-scale nutrient balance concepts.

- Establish long-term modeling and monitoring frameworks for livestock-intensive watersheds or regions to validate modeling assumptions and track impacts of various manure adaptations.

\section{EDUCATIONAL RECOMMENDATIONS}

Existing extension and outreach strategies have been effective in achieving significant improvements in field-scale nutrient management. There is an opportunity to leverage these strategies to increase awareness and adoption of whole-farm and regional nutrient balances. Future actions may include the following:

- Develop educational modules (for BS-level students in agriculture and life sciences) and training resources (for agricultural consultants and operators) that introduce the concept of whole-farm and regional nutrient balance and assemble the necessary tools and record-keeping processes to facilitate implementation.

- Engage industry stakeholders critical to building awareness and planning of future implementation. Key stakeholders include industry commodity associations, the USDA-NRCS, regulatory agencies at federal and state level, animal industry sustainability organizations, non-governmental organizations (NGOs), and potential funding organizations.

\section{CONCLusions}

Improving nutrient management in agricultural systems is critical to reduce nutrient pollution and its adverse impacts on the health and well-being of ecosystems and communities. Developing nutrient balances at varying spatial scales provides a consistent basis for quantitative benchmarking of nutrient cycling as a first step toward improving management. The drivers for nutrient imbalance at each scale were briefly discussed with potential strategies to reduce these imbalances. The concept of thresholds for action was introduced to tie measures currently in place for nutrient management at field, farm, and regional scales. Establishing productivity-related thresholds for action for field and farm nutrient balances was shown to be a promising approach that is acceptable to agricultural producers and effective in reducing nutrient imbalances over time. On the other hand, the threshold for action at regional scale is currently tied to impacts, as exemplified by the impairment trigger for water quality through the TMDL process. Establishing watershed- or county-based nutrient balances can serve as a comparative basis for prioritizing interventions to address nutrient imbalances. Gaps and recommendations for research and outreach communities to advance the use of these concepts were summarized. There remains a need for a collaborative, goal-oriented process that brings agricultural producers, integrators, as well as regulatory agencies and research bodies together to establish processes and set goals to balance nutrient flows across the landscape.

\section{ACKNOWLEDGEMENTS}

This review is a contribution from the USDA Multistate Research Project (S1074: Future Challenges in Animal Production Systems: Seeking Solutions through Focused Facilitation). We would like to acknowledge project participants whose comments and discussions helped improve this review.

\section{REFERENCES}

Aarts, H. F., Biewing, E. E., \& Van Keulen, H. (1992). Dairy farming systems based on efficient nutrient management. Netherlands J. Agric. Sci., 40(3), 285-299. https://doi.org/10.18174/njas.v40i3.16514

Andersen, D. S., \& Pepple, L. M. (2017). A county-level assessment of manure nutrient availability relative to crop nutrient capacity in Iowa: Spatial and temporal trends. Trans. ASABE, 60(5), 1669-1680. https://doi.org/10.13031/trans.12417

Araji, A. A., Abdo, Z. O., \& Joyce, P. (2001). Efficient use of animal manure on cropland-economic analysis. Bioresour. Tech., 79(2), 179-191. https://doi.org/10.1016/S09608524(01)00042-6

ASCE. (2017). Total maximum daily load analysis and modeling: Assessment of the practice. Reston, VA: ASCE.

Barker, J. C., \& Zublena, J. P. (1995). Livestock manure nutrient assessment in North Carolina. Final Report. Raleigh, NC: North Carolina State University Extension Service.

Bélanger, G., Ziadi, N., Walsh, J. R., Richards, J. E., \& Milburn, P. H. (2003). Residual soil nitrate after potato harvest. J. Environ. Qual., 32(2), 607-612. https://doi.org/10.2134/jeq2003.6070

Boesch, D. F., Brinsfield, R. B., \& Magnien, R. E. (2001). Chesapeake Bay eutrophication: Scientific understanding, ecosystem restoration, and challenges for agriculture. J. Environ. Qual., 30(2), 303-320. https://doi.org/10.2134/jeq2001.302303x

Bonifacio, H. F., Rotz, C. A., Leytem, A. B., Waldrip, H. M., \& Todd, R. W. (2015). Process-based modeling of ammonia and nitrous oxide emissions from open-lot beef and dairy facilities. Trans. ASABE, 58(3), 827-846.

https://doi.org/10.13031/trans.58.11112

Bruulsema, T. (2009). Recommendation development under 4R nutrient stewardship. Proc. North Central Extension-Industry Soil Fertility Conf. Retrieved from https://northcentralfertility.com/proceedings/?action=abstract\&i $\mathrm{d}=4250 \&$ title $=$ Recommendation + Development + Under $+4 \mathrm{R}+\mathrm{Nut}$ rient + Stewardship\&search $=$ years

Cao, Y., Wang, X., Liu, L., Velthof, G. L., Misselbrook, T., Bai, Z., $\&$ Ma, L. (2020). Acidification of manure reduces gaseous emissions and nutrient losses from subsequent composting process. J. Environ. Mgmt., 264, article 110454. https://doi.org/10.1016/j.jenvman.2020.110454

Cela, S., Ketterings, Q. M., Czymmek, K. J., Soberon, M., \& Rasmussen, C. (2014a). Whole-farm nutrient mass balance benchmarks for New York dairies. Ithaca, NY: Cornell University. Retrieved from https://ecommons.cornell.edu/bitstream/handle/1813/37980/CN 
C2014_16_Ketterings.pdf;jsessionid=3E6AC00E8D1024725C6 E0A0E50F83638? sequence $=1$

Cela, S., Ketterings, Q. M., Czymmek, K., Soberon, M., \& Rasmussen, C. (2014b). Characterization of nitrogen, phosphorus, and potassium mass balances of dairy farms in New York State. J. Dairy Sci., 97, 7614-7632. https://doi.org/10.3168/jds.2014-8467

Cela, S., Ketterings, Q. M., Czymmek, K., Soberon, M., \& Rasmussen, C. (2015). Long-term trends of nitrogen and phosphorus mass balances on New York state dairy farms. $J$. Dairy Sci., 98, 7052-7070. https://doi.org/10.3168/jds.20159776

Centner, T. J., \& Newton, G. L. (2011). Reducing concentrated animal feeding operations permitting requirements. J. Animal Sci., 89(12), 4364-4369. https://doi.org/10.2527/jas.2011-4256

Cooper, J., Lombardi, R., Boardman, D., \& Carliell-Marquet, C. (2011). The future distribution and production of global phosphate rock reserves. Resour. Conserv. Recycling, 57, 78-86. https://doi.org/10.1016/j.resconrec.2011.09.009

Deviney, A., Classen, J., Bruce, J., \& Sharara, M. (2021). Sustainable swine manure management: A tale of two agreements. Sustainability, 13(1), 15. https://doi.org/10.3390/su13010015

Dobermann, A. (2007). Nitrogen use efficiency: Measurement and management. Proc. IFA Intl. Workshop on Fertilizer Best Management Practices. Paris, France: International Fertilizer Industry Association.

Dodds, W. K., Bouska, W. W., Eitzmann, J. L., Pilger, T. J., Pitts, K. L., Riley, A. J., ... Thornbrugh, D. J. (2009). Eutrophication of U.S. freshwaters: Analysis of potential economic damages. Environ. Sci. Tech., 43(1), 12-19. https://oi.org/10.1021/es801217q

Domingo, N. G., Balasubramanian, S., Thakrar, S. K., Clark, M. A., Adams, P. J., Marshall, J. D., ... Hill, J. D. (2021). Air qualityrelated health damages of food. Proc. Natl. Acad. Sci., 118(20), e2013637118. https://doi.org/10.1073/pnas.2013637118

Dou, Z., Lanyon, L. E., Ferguson, J. D., Kohn, R. A., Boston, R. C., \& Chalupa, W. (1998). An integrated approach to managing nitrogen on dairy farms: Evaluating farm performance using the dairy nitrogen planner. Agron. J., 90(5), 573-581. https://doi.org/10.2134/agronj1998.00021962009000050001x

Ferket, P. R., van Heugten, E., van Kempen, T. A., \& Angel, R. (2002). Nutritional strategies to reduce environmental emissions from nonruminants. J. Animal Sci., 80(S2), E168-E182. https://doi.org/10.2527/animalsci2002.80E-Suppl_2E168x

Frink, C. R. (1969). Water pollution potential estimated from farm nutrient budgets. Agron. J., 61(4), 550-553. https://doi.org/10.2134/agronj1969.00021962006100040020x

Fulton, J., Hawkins, E., Taylor, R., \& Franzen, A. (2018). Chapter 5: Yield monitoring and mapping. In D. K. Shannon, D. E. Clay, $\&$ N. R. Kitchen (Eds.), Precision agriculture basics (pp. 6378). Madison, WI: ASA, CSSA, SSSA. https://doi.org/10.2134/precisionagbasics.2016.0089

Galloway, J. N., Leach, A. M., Bleeker, A., \& Erisman, J. W. (2013). A chronology of human understanding of the nitrogen cycle. Phil. Trans. Royal Soc. B, 368(1621), article 20130120. https://doi.org/10.1098/rstb.2013.0120

Garrett, R. D., Ryschawy, J., Bell, L. W., Cortner, O., Ferreira, J., Garik, A. V., ... Valentim, J. F. (2020). Drivers of decoupling and recoupling of crop and livestock systems at farm and territorial scales. Ecol. Soc., 25(1), article 24. https://doi.org/10.5751/ES-11412-250124

Gollehon, N. R., Caswell, M., Ribaudo, M., Kellogg, R. L., Lander, C., \& Letson, D. (2001). Confined animal production and manure nutrients. Agricultural Information Bulletin 771:39. Washington, DC: USDA-ERS Resource Economics Division.
Gollehon, N. R., Kellogg, R. L., \& Moffitt, D. C. (2016). Estimates of recoverable and non-recoverable manure nutrients based on the Census of Agriculture 2012 results. Washington, DC: USDA-NRCS.

Goolsby, D. A., Battaglin, W. A., Aulenbach, B. T., \& Hooper, R. P. (2000). Nitrogen flux and sources in the Mississippi River basin. Sci. Total Environ., 248(2), 75-86. https://doi.org/10.1016/S0048-9697(99)00532-X

Hale, R. L., Hoover, J. H., Wollheim, W. M., \& Vörösmarty, C. J. (2013). History of nutrient inputs to the northeastern United States, 1930-2000. Global Biogeochem. Cycles, 27(2), 578-591. https://doi.org/10.1002/gbc.20049

Hilimire, K. (2011). Integrated crop/livestock agriculture in the United States: A review. J. Sustain. Agric., 35(4), 376-393. https://doi.org/10.1080/10440046.2011.562042

Holly, M. A., Gunn, K. M., Rotz, C. A., \& Kleinman, P. J. (2019). Management characteristics of Pennsylvania dairy farms. Appl. Animal Sci., 35(3), 325-338. https://doi.org/10.15232/aas.201801833

Hong, N., Scharf, P. C., Davis, J. G., Kitchen, N. R., \& Sudduth, K. A. (2007). Economically optimal nitrogen rate reduces soil residual nitrate. J. Environ. Qual., 36(2), 354-362. https://doi.org/10.2134/jeq2006.0173

Howarth, R. W., Sharpley, A., \& Walker, D. (2002). Sources of nutrient pollution to coastal waters in the United States: Implications for achieving coastal water quality goals. Estuaries, 25(4), 656-676. https://doi.org/10.1007/BF02804898

Hristov, A. N., Hanigan, M., Cole, A., Todd, R., McAllister, T. A., Ndegwa, P. M., \& Rotz, A. (2011). Ammonia emissions from dairy farms and beef feedlots. Canadian J. Animal Sci., 91(1), 135. https://doi.org/10.4141/CJAS10034

Hristov, A. N., Hazen, W., \& Ellsworth, J. W. (2006). Efficiency of use of imported nitrogen, phosphorus, and potassium and potential for reducing phosphorus imports on Idaho dairy farms. J. Dairy Sci., 89, 3702-3712. https://doi.org/10.3168/jds.S00220302(06)72411-0

IPNI. (2012). NuGIS: Nutrient use geographic information system. Norcross, GA: International Plant Nutrition Institute. Retrieved from http://nugis.ipni.net/.

Kast, J. B., Apostel, A. M., Kalcic, M. M., Muenich, R. L., Dagnew, A., Long, C. M., ... Martin, J. F. (2021). Source contribution to phosphorus loads from the Maumee River watershed to Lake Erie. J. Environ. Mgmt., 279, article 111803. https://doi.org/10.1016/j.jenvman.2020.111803

Keller, A. A., \& Cavallaro, L. (2008). Assessing the U.S. Clean Water Act 303(d) listing process for determining impairment of a waterbody. J. Environ. Mgmt., 86(4), 699-711. https://doi.org/10.1016/j.jenvman.2006.12.013

Kellogg, R. L., Lander, C. H., Moffitt, D. C., \& Gollehon, N. R. (2000). Manure nutrients relative to the capacity of cropland and pastureland to assimilate nutrients. Proc. Water Environ. Fed., 2000(16). https://doi.org/10.2175/193864700784994812

Ketterings, Q. M., Czymmek, K. J., Beegle. D., B., Chase, L. E., \& Rasmussen, C. N. (2012). Systematic nutrient balances in dairy farm systems of the northeast and mid-Atlantic regions of the United States. J. Agric. Sci., 4(11). https://doi.org/10.5539/jas.v4n11p1

Klausner, S. (1995). Nutrient management planning. In K. Steele (Ed.), Animal waste and the land-water interface (pp. 383-392). New York, NY: Lewis Publishing.

Kleinman, P. J., Fanelli, R. M., Hirsch, R. M., Buda, A. R., Easton, Z. M., Wainger, L. A., ... Shenk, G. W. (2019). Phosphorus and the Chesapeake Bay: Lingering issues and emerging concerns for agriculture. J. Environ. Qual., 48(5), 1191-1203. https://doi.org/10.2134/jeq2019.03.0112 
Koelsch, R. (2005). Evaluating livestock system environmental performance with whole-farm nutrient balance. J. Environ. Qual., 34(1), 149-155. https://doi.org/

Koelsch, R. K., \& Ketterings, Q. M. (2017). Whole-farm nutrient balance: Systems approach to dairy nutrient planning. In D. K. Beebe (Ed.), Large dairy herd management (3rd Ed., pp. 193210). Champaign, IL: American Dairy Science Association. https://doi.org/10.3168/ldhm.0314

Koelsch, R. K., \& Lesoing, (1999). Nutrient balance on Nebraska livestock confinement systems. J. Animal Sci., 77(supp. 2), 6371. https://doi.org/10.2527/1999.77suppl_263x

Lanyon, L. E., \& Beegle, D. B. (1993). A nutrient management approach for Pennsylvania: Plant nutrient stocks and flows. Penn State Agronomy Facts 38-B. State College, PA: Pennsylvania State University.

Libra, R. D., Wolter, C. F., \& Langel, R. J. (2004). Nitrogen and phosphorus budgets for Iowa and Iowa watersheds. Technical Information Series 47. Iowa City, IA: Iowa Geological Survey.

Liu, Q., Wang, J., Hou, Y., van Dijk, K., Qin, W., Lesschen, J. P., .. Oenema, O. (2020). Chapter 1.1: Global nutrient flows and cycling in food systems. In Biorefinery of inorganics: Recovering mineral nutrients from biomass and organic waste (pp. 1-22). New York, NY: Wiley.

https://doi.org/10.1002/9781118921487.ch1-1

Liu, Z., Sharara, M., Gunasekaran, S., \& Runge, T. M. (2016). Effects of large-scale manure treatment processes on pathogen reduction, protein distributions, and nutrient concentrations. Trans. ASABE, 59(2), 695-702. https://doi.org/10.13031/trans.59.11227

Mallarino, A. P., \& Wittry, D. J. (2010). Crop yield and soil phosphorus as affected by liquid swine manure phosphorus application using variable-rate technology. SSSA J., 74(6), 22302238. https://doi.org/10.2136/sssaj2009.0215

MacDonald, J. M., \& McBride, W. D. (2009). The transformation of U.S. livestock agriculture: Scale, efficiency, and risks. Economic Information Bulletin No. 43. Washington, DC: USDA-ERS. https://doi.org/10.2139/ssrn.1354028

McLellan, E. L., Cassman, K. G., Eagle, A. J., Woodbury, P. B., Sela, S., Tonitto, C., ... van Es, H. M. (2018). The nitrogen balancing act: Tracking the environmental performance of food production. BioScience, 68(3), 194-203. https://doi.org/10.1093/biosci/bix164

Metson, G. S., Lin, J., Harrison, J. A., \& Compton, J. E. (2017). Linking terrestrial phosphorus inputs to riverine export across the United States. Water Res., 124, 177-191. https://doi.org/10.1016/j.watres.2017.07.037

Miller, C. M., Price, P. L., \& Meyer, D. (2017). Mass balance analyses of nutrients on California dairies to evaluate data quality for regulatory review. Sci. Total Environ., 579, 37-46. https://doi.org/10.1016/j.scitotenv.2016.10.092

Morris, T. F., Murrell, T. S., Beegle, D. B., Camberato, J. J., Ferguson, R. B., Grove, J., ... Yang, H. (2018). Strengths and limitations of nitrogen rate recommendations for corn and opportunities for improvement. Agron. J., 110(1), 1-37. https://doi.org/10.2134/agronj2017.02.0112

Naylor, R., Steinfeld, H., Falcon, W., Galloway, J., Smil, V., Bradford, E., ... Mooney, H. (2005). Losing the links between livestock and land. Science, 310(5754), 1621-1622. https://doi.org/10.1126/science.1117856

Ni, J. Q., Heber, A. J., \& Lim, T. T. (2018). Ammonia and hydrogen sulfide in swine production. In Air quality and livestock farming (pp. 29-47). Boca Raton, FL: CRC Press. https://doi.org/10.1201/9781315738338-3

Oenema, O., Kros, H., \& de Vries, W. (2003). Approaches and uncertainties in nutrient budgets: Implications for nutrient management and environmental policies. European J. Agron., 20(1), 3-16. https://doi.org/10.1016/S1161-0301(03)00067-4

Ohio EPA. (2018). Nutrient mass balance study for Ohio's major rivers. Columbus, $\mathrm{OH}$ : Ohio EPA. Retrieved from https://epa.ohio.gov/Portals/35/documents/Nutrient-MassBalance-Study-2020.pdf

Osmond, D. L., Hoag, D. L., Luloff, A. E., Meals, D. W., \& Neas, K. (2015). Farmers' use of nutrient management: Lessons from watershed case studies. J. Environ. Qual., 44(2), 382-390. https://doi.org/10.2134/jeq2014.02.0091

Pearce, A., \& Maguire, R. (2020). The state of phosphorus balance on 58 Virginia dairy farms. J. Environ. Qual., 49(2), 324-334. https://doi.org/10.1002/jeq2.20054

Porter, S. A., \& James, D. E. (2020). Using a spatially explicit approach to assess the contribution of livestock manure to Minnesota's agricultural nitrogen budget. Agronomy, 10(4), article 480. https://doi.org/10.3390/agronomy10040480

Ransom, C. J., Kitchen, N. R., Camberato, J. J., Carter, P. R., Ferguson, R. B., Fernández, F. G., ... Shanahan, J. F. (2020). Corn nitrogen rate recommendation tools' performance across eight U.S. Midwest Corn Belt states. Agron. J., 112(1), 470-492. https://doi.org/10.1002/agj2.20035

Robertson, D. M., \& Saad, D. A. (2021). Nitrogen and phosphorus sources and delivery from the Mississippi/Atchafalaya River basin: An update using 2012 SPARROW models. JAWRA, 57(3), 406-429. https://doi.org/10.1111/1752-1688.12905

Rotz, C. A. (2012). The Integrated Farm System Model: Software for evaluating the performance, environmental impact, and economics of farming systems. Washington, DC: USDA-ARS. Retrieved from https://www.ars.usda.gov/ARSUserFiles/np212/LivestockGRA CEnet/IFSM.pdf

Ruddy, B. C., Lorenz, D. L., \& Mueller, D. K. (2006). County-level estimates of nutrient inputs to the landsurface of the conterminous United States, 1982-2001. USGS Scientific Investigations Report 2006-5012. 23. Reston, VA: U.S. Geological Survey. https://doi.org/10.3133/sir20065012

Rufino, M. C., Brandt, P., Herrero, M., \& Butterbach-Bahl, K. (2014). Reducing uncertainty in nitrogen budgets for African livestock systems. Environ. Res. Lett., 9(10), article 105008. https://doi.org/10.1088/1748-9326/9/10/105008

Sabo, R. D., Clark, C. M., Bash, J., Sobota, D., Cooter, E., Dobrowolski, J. P., ... Compton, J. E. (2019). Decadal shift in nitrogen inputs and fluxes across the contiguous United States: 2002-2012. J. Geophys. Res. Biogeosci., 124(10), 3104-3124. https://doi.org/10.1029/2019JG005110

Sampat, A. M., Hu, Y., Sharara, M., Aguirre-Villegas, H., RuizMercado, G., Larson, R. A., \& Zavala, V. M. (2019). Coordinated management of organic waste and derived products. Comput. Chem. Eng., 128, 352-363. https://doi.org/10.1016/j.compchemeng.2019.06.008

Sharara, M. A., Runge, T., Larson, R., \& Primm, J. G. (2018). Techno-economic optimization of community-based manure processing. Agric. Syst., 161, 117-123. https://doi.org/10.1016/j.agsy.2018.01.006

Sharpley, A. N., Kleinman, P. J., Jordan, P., Bergström, L., \& Allen, A. L. (2009). Evaluating the success of phosphorus management from field to watershed. J. Environ. Qual., 38(5), 1981-1988. https://doi.org/10.2134/jeq2008.0056

Shen, J., Chen, D., Bai, M., Sun, J., Coates, T., Lam, S. K., \& Li, Y. (2016). Ammonia deposition in the neighbourhood of an intensive cattle feedlot in Victoria, Australia. Sci. Rep., 6(1), article 32793. https://doi.org/10.1038/srep32793

Sheriff, G. (2005). Efficient waste? Why farmers over-apply nutrients and the implications for policy design. Appl. Econ. 
Perspect. Policy, 27(4), 542-557. https://doi.org/10.1111/j.14679353.2005.00263.x

Shortle, J., \& Horan, R. D. (2017). Nutrient pollution: A wicked challenge for economic instruments. Water Econ. Policy, 03(02), article 1650033. https://doi.org/10.1142/s2382624x16500338

Sims, J. T. (1993). Environmental soil testing for phosphorus. $J$. Prod. Agric., 6(4), 501-507. https://doi.org/10.2134/jpa1993.0501

Sitthaphanit, S., Limpinuntana, V., Toomsan, B., Panchaban, S., \& Bell, R. W. (2009). Fertiliser strategies for improved nutrient use efficiency on sandy soils in high rainfall regimes. Nutr. Cycling Agroecosyst., 85(2), 123-139. https://doi.org/10.1007/s10705009-9253-Z

Smolen, M., Storm, D., Peel, D., \& Kenkel, P. (1994). Mass balance analysis of nutrient flow through feed and waste in the livestock industry in the Southern Plains. Proc. Great Plains Animal Waste Conf. on Confined Animal Production and Water Quality: Balancing Animal Production and the Environment (pp. 19-21). Denver, CO: Great Plains Publishing.

Soberon, M. A., Cela, S., Ketterings, Q. M., Rasmussen, C. N., \& Czymmek, K. J. (2015). Changes in nutrient mass balances over time and related drivers for $54 \mathrm{New}$ York State dairy farms. $J$. Dairy Sci., 98(8), 5313-5329. https://doi.org/10.3168/jds.20149236

Spears, R. A., Kohn, R. A., \& Young, A. J. (2003a). Whole-farm nitrogen balance on western dairy farms. J. Dairy Sci., 86, 41784186. https://doi.org/10.3168/jds.S0022-0302(03)74033-8

Spears, R. A., Young, A. J., \& Kohn, R. A. (2003b). Whole-farm phosphorus balance on western dairy farms. J. Dairy Sci., 86, 688-695. https://doi.org/10.3168/jds.S0022-0302(03)73648-0

Spiegal, S., Kleinman, P. J., Endale, D. M., Bryant, R. B., Dell, C., Goslee, S., ... Yang, Q. (2020). Manuresheds: Advancing nutrient recycling in U.S. agriculture. Agric. Syst., 182, article 102813. https://doi.org/10.1016/j.agsy.2020.102813

Stackpoole, S. M., Stets, E. G., \& Sprague, L. A. (2019). Variable impacts of contemporary versus legacy agricultural phosphorus on U.S. river water quality. Proc. Natl. Acad. Sci., 116(41), 20562-20567. https://doi.org/10.1073/pnas.1903226116

Swink, S. N., Ketterings, Q. M., Chase, L. E., Czymmek, K. J., \& van Amburgh, M. E. (2011). Nitrogen balances for New York State: Implications for manure and fertilizer management. J. Soil Water Cons., 66(1), 1-17. https://doi.org/10.2489/jswc.66.1.1
USEPA. (2020). National Pollutant Discharge Elimination System (NPDES): Animal feeding operations (AFOs). Washington, DC: U.S. Environmental Protection Agency. Retrieved from https://www.epa.gov/npdes/animal-feeding-operations-afos

USDA-NASS. (2019). 2017 Census of Agriculture (issued April 2019). United States Summary and State Data: Vol. 1, Geographic Area Series, Part 51. Washington, DC: USDANASS. Retrieved from

https://www.nass.usda.gov/Publications/AgCensus/2017/Full_R eport/Volume_1,_Chapter_1_US/usv1.pdf

USDA-NASS. (2021). Guide to NASS surveys and programs: Agricultural yield. Washington, DC: USDA-NASS. Retrieved from

https://www.nass.usda.gov/Surveys/Guide_to_NASS_Surveys/ Agricultural_Yield/index.php

USDA-NRCS. (2019). Conservation Practice Standard Nutrient Management Code 590. Washington, DC: USDA-NRCS. Retrieved from https://www.nrcs.usda.gov/Internet/FSE_DOCUMENTS/stelprd b1192371.pdf

Waldrip, H. M., Rotz, C. A., Hafner, S. D., Todd, R. W., \& Cole, N. A. (2014). Process-based modeling of ammonia emission from beef cattle feedyards with the integrated farm systems model. $J$. Environ. Qual., 43(4), 1159-1168. https://doi.org/10.2134/jeq2013.09.0354

Watts, P. J., Gardnes, E. A., Tucker, R. W., \& Casey, K. D. (1994). Mass-balance approach to design of nutrient management systems at cattle feedlots. In D. E. Storm \& K. G. Casey (Eds.), Proc. Great Plains Animal Waste Conf. on Confined Animal Production and Water Quality: Balancing Animal Production and the Environment (pp. 27-33). Denver, CO: Great Plains Agricultural Council.

Williams, P., Eising, E., \& Malley, D. F. (2020). Industrial-scale continuous on-line analysis of liquid hog manure by NIRS. NIR News, 31(7-8), 25-29. https://doi.org/10.1177/0960336020978714

Zhang, X., Davidson, E. A., Zou, T., Lassaletta, L., Quan, Z., Li, T., $\&$ Zhang, W. (2020). Quantifying nutrient budgets for sustainable nutrient management. Global Biogeochem. Cycles, 34(3), e2018GB006060. https://doi.org/10.1029/2018GB006060

Zhang, X., Ren, C., Gu, B., \& Chen, D. (2021). Uncertainty of nitrogen budget in China. Environ. Pollut., 286, article 117216. https://doi.org/10.1016/j.envpol.2021.117216 